Western University Scholarship@Western

Centre for the Study of International Economic

Centre for the Study of International Economic

Relations Working Papers

Relations

1986

\title{
International Trade and the Acquisition of Skills
}

Elias Dinopoulos

Ian Wooton

Follow this and additional works at: https://ir.lib.uwo.ca/economicscsier_wp

Part of the Economics Commons

Citation of this paper:

Dinopoulos, Elias, Ian Wooton. "International Trade and the Acquisition of Skills." Centre for the Study of International Economic Relations Working Papers, 8606C. London, ON: Department of Economics, University of Western Ontario (1986). 
THE CENTRE FOR THE STUDY OF INTERNATIONAL ECONOMIC RELATIONS

$$
\text { WORKING PAPER NO. } 8606 \mathrm{C}
$$

INTERNATIONAL TRADE AND THE ACQUISITION OF SKILLS

\author{
Elias Dinopoulos \\ and
}

Ian Wooton

This paper contains preliminary findings from research work still in progress and should not be quoted without prior approval of the authors.

DEPARTMENT OF ECONOMICS THE UNIVERS ITY OF WESTERN ONTARIO LONDON, CANADA N6A $5 \mathrm{C} 2$

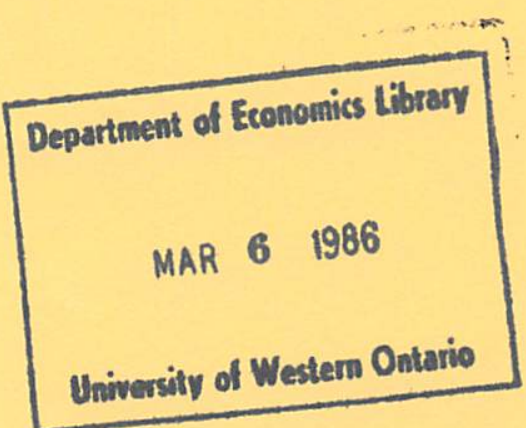


INTERNATIONAL TRADB AND THB ACQUISITION OF SKILTS

by

Blias Dinopoulos ${ }^{*}$

Michigan State University and the Centre for the Study of International

Bconomic Relations, University of Western Ontario

and

Ian Wooton ${ }^{*}$

University of Western Ontario

February 1986

Department of Econumics Libraty

MAR 61986

University of Western Ontario 


\section{Introduction}

This paper represents an attempt to incorporate human capital accumulation into the standard, two-sector, general-equilibrium model of international trade. As such, it is complementary to the paper of Kenen (1965) and that of Findlay and Kierzkowski (1983). The focus of interest in this paper is the potential for intertemporal substitution of human capital for physical capital in the production of goods.

Kenen's model incorporates three factors of production: a mobile factor (capital) and two factors (labour and land) specific to the production of intermediate inputs (educated labour and fertilized land, respectively). These intermediate inputs are then used to produce the traded output.

While all labour in Kenen's paper is transformed into uniformly skilled labour, this is not the case in the paper of Findlay and Kierzkowski. Their interests lie in the asymmetric accumulation of human capital, such that an economy employs both educated and uneducated workers, the relative number of each being determined endogenously. Goods are characterized by their relative intensity of skilled to non-skilled inputs, and countries that acquire relatively large skill endowments are those that have large endowments of the specific input used in education, relative to their labour supplies.

The model used in this paper is distinct from both of the above papers, though it shares elements of both. There are only two factors of production, neither being specific to a single production activity. ${ }^{1}$ Education, the process resulting in skilled labour, uses inputs of physical capital and hence results in a substitution between two categories of capital--physical and 
human. Unlike Findlay and Kierzkowski, the quantity of education which can be invested in is endogenous, and so all workers will receive the same education rather than being divided into classes, with one group acquiring no skills and members of the other getting a fixed quantity. of education.

The model is also quite distinct from those considering intersectoral reallocations of factors [see, for example, Mussa (1978) and Neary (1978)]. In this model factors are perfectly mobile between sectors, the costly adjustments result from the time investment in converting capital input in manufacturing to labour input.

In the sections that follow the model will be laid out and the autarkic equilibrium established. The full two-country general equilibrium will then be discussed.

\section{The Kodel}

Let there be two generations of agents in the economy, $\mathrm{N}$ identical agents of each generation. In the first period of life an agent (termed, say, a "student") consumes some of each of the two goods, $X$ and $Y$, and may also acquire an education through the purchase of educational services, $B .^{2}$ In the second and final period of life, the agent (now termed, say, a "worker") consumes $X$ and $Y$ and works in their production. There is a fixed endowment of capital in the economy, $K$, that does not depreciate over time. This capital stock is assumed to be passed down through the generations as a bequest for workers to own and use both in the production of $X$ and $Y$ and in the provision of education. 3

The quantity of labour services available for use in production in any period depends upon the quantity of education acquired by the workers in the 
previous period. Now,

$$
\dot{B}^{t}=H\left[K_{B}^{t}, N^{t}\right]
$$

where $\mathrm{B}^{t}$ is the quantity of skills acquired by students of generation $t$ (that is, born in period $t$ ) and $k_{B}^{t}$ is the quantity of capital used in its provision. $\mathrm{N}^{\mathrm{t}}$ is assumed to be constant over generations. It is assumed that the function $H$ is linearly homogeneous in its arguments, with positive first partial derivatives and negative second partial derivatives, and thus (1) may be rewritten as:

$$
e^{t}=E^{t}, \bar{N}=H\left[k_{E}^{t}, 1\right]=h\left[k_{E}\right]
$$

where $k_{B}^{t}$ is the quantity of capital services used in education per student. The total quantity of labour services an individual worker can offer is defined as the sum of "natural" skills (those the worker was born with or acquires in youth without the aid of formal education--equal to unity) and the quantity of education he undergoes. Thus the total supply of workers in period $t$ is determined by the previous period's educational input:

$$
L^{t}=\left(1+e^{t-1}\right) \bar{N}=E^{t-1}+\bar{N}
$$

The capital available for goods manufacturing in period $t$ is

$$
K_{M}^{t}=\bar{K}-K_{E}^{t}
$$

Production of goods $X$ and $Y$ is according to production functions exhibiting constant returns to scale:

$$
\begin{aligned}
x^{t} & =F\left[K_{X}^{t}, L_{X}^{t}\right] \\
Y^{t} & =G\left[K_{Y}^{t}, L_{Y}^{t}\right]
\end{aligned}
$$


where:

$$
\begin{aligned}
& x_{X}^{t}+x_{Y}^{t}=x_{Y}^{t} \\
& L_{X}^{t}+L_{Y}^{t}=L^{t}
\end{aligned}
$$

The supply of labour to manufacturing can never be less than $\overline{\mathrm{s}}$. The maximum quantity of labour will result from all capital being employed in education. As goods production requires non-zero inputs of both capital and labour, not all capital can be employed in the education sector.

Agents maximize their lifetime utility through their intertemporal consumption choice and educational investment decision. Assume that the utility function is time separable, such that the lifetime utility of an individual of generation $t$ is:

$$
u^{t}=u\left[c_{X}^{t 1}, c_{Y}^{t 1}\right]+\frac{1}{1+d} u\left[c_{X}^{t 2} \cdot c_{Y}^{t 2}\right]
$$

where $d>0$ is the rate of discount on future consumption and $c_{j}^{t i}$ is the consumption of good $J$ in the $i^{\text {th }}$ period of life by an agent of generation $t$. It is assumed that agents expect current prices to persist into the next period. $^{4}$

In order for individuals to be able to consume in their first period, when they have no income, there has to be some provision of loans, repayable in the second period. They cannot borrow from workers in the previous generation as those agents will die before being repaid. Therefore assume that these loans are made, in the form of real bonds, by the government of the country which charges interest at the market-clearing rate $R$ per period on the principal. 
Suppose the relative prices in the manufacturing part of the economy in period $t$ are:

$$
P^{t}=\left(P_{Y}^{t} / P_{X}^{t}\right)
$$

If the country is diversified in its goods production (which it will be in autarky but need not be when it trades internationally), this price will determine the relative capital intensities in production and the returns to the factors of production. Assume that, at any relative price, the production of good $\mathrm{X}$ is intensive in its use of capital relative to the production of good $Y$. The return to capital in the non-traded, educational sector must equal that in manufacturing. Thus:

$$
\begin{aligned}
F_{L}^{t} & =p^{t} G_{L}^{t}=w\left(p^{t}\right) \\
F_{K}^{t} & =p^{t} G_{K}^{t}=q^{t} H_{K}^{t}=r\left(p^{t}\right)
\end{aligned}
$$

where $\mathrm{q}^{t}$ is the relative price of education in terms of good $\mathrm{X}$ :

$$
q^{t}=\left(P_{B}^{t} / P_{E}^{t}\right)
$$

and the subscripted terms represent the partial derivatives of the corresponding production function. The allocation of resources to manufacturing depends on the quantity of capital allocated to education which, in turn, depends on the demand for education. Domestic demand for all goods may be determined by maximizing the representative agent's lifetime utility which, due to the assumptions of identical agents and homogeneity in production and utility, is the same as maximizing the utility of a generation. Thus maximize (9) subject to: 


$$
\begin{aligned}
& c_{X}^{t 1}+p^{t} c_{Y}^{t 1}+q^{t} e^{t}=b^{t} \\
& c_{x}^{t 2}+p^{t+1} c_{Y}^{t 2}+(1+R) b^{t}=w\left(p^{t+1}\right)\left(1+e^{t}\right)+r\left(p^{t+1}\right) \bar{k}
\end{aligned}
$$

where $b^{t}$ is the borrowing made for period 1 consumption (a bond denominated in units of good $x$ ) and $\bar{k}$ is the capital endowment per agent (of $a$ generation), i.e.,

$$
\overline{\mathbf{k}}=\overline{\mathrm{k}}, \overline{\mathbf{v}} \text {, }
$$

First-order conditions yield:

$$
\begin{aligned}
& \frac{u_{Y}^{t 1}}{u_{X}^{t 1}}=p^{t}, \frac{u_{Y}^{t 2}}{u^{t 2}}=p^{t+1} \\
& \frac{u_{X}^{t 1}}{u_{X}^{t 2}}=\frac{p^{t+1}}{u^{t}} \frac{u_{Y}^{t 1}}{u_{Y}^{t 2}}=(1+R) \\
& q^{t}=\frac{w(p)}{(1+R)}
\end{aligned}
$$

Some observations may be made about the above conditions. Firstly, (16) determines the division of consumption between $X$ and $Y$ in any one period on the basis of the prevailing relative price of the two goods, while (17) allocates expenditure between the first and second periods of an agent's lifetime. Were the rate of interest on loans equal to the private rate of discount on consumption, and were relative prices constant over time, then the consumption profile of an individual over his/her lifetime would be flat. It is clear from (18) that the demand for, and hence the price of, education depends on the return to the skilled labour when it is employed in the following period. 
In the steady-state, with unchanging population and capital endowment, all variables will be constant and thus all time superscripts may be dropped from equations (14) through (18). Combining (18) and (12) yields:

$$
H_{K}\left[K_{E}, \bar{N}\right]=(1+R) \frac{r(p)}{W(p)}
$$

Thus, with the assumption that there are no factor-intensity reversals in goods production, the steady-state commodity price ratio determines a unique allocation of capital to the education sector, $K_{B}^{\star}$. Rewriting (19), and substituting $h^{\prime}\left(k_{B}\right)$ for ${ }_{K}\left[K_{B}, \bar{N}\right]$ :

$$
r(p)=\frac{h^{\prime}\left(k_{B}\right) w(p)}{(1+R)} \text {, }
$$

the return to capital in manufacturing is equal to the discounted return to the labour it is used to "create" through education. This result is independent of the rate of time preference of the agent.

This result is illustrated in Figure 1, which shows the intertemporal allocation of consumption in the first quadrant and the allocation of physical capital services to education in the second quadrant. Let $c^{1}$ be the value of consumption for the representative agent in the first period of life and let $c^{2}$ be the corresponding value for the second period; that is,

$$
c^{i}=c_{X}^{i}+p c_{Y}^{i} \text {, for } i=1,2
$$

Suppose that there were no educational investment, then the supply of labour would be $\bar{A}$ and all physical capital would be employed in manufacturing goods. At the equilibrium price ratio, let the value of these factor services be $O A$. 
The agents spend this income on consumption in each of the two periods of their lives. The intertemporal budget line would be $A^{\prime}$ which has slope of $-(1+R)$, the price of consuming in the first period when income is earned only in the second period. Bducation requires a reallocation of capital from manufacturing. The horizontal axis in the second quadrant represents the value of borrowing by the student to acquire capital for education, with the curve from A showing the increase in the agent's income in the following period resulting from that educational investment. The optimal acquisition of education (corresponding to equation (20)) occurs at point $B$ where the education function is tangent to an intertemporal budget line with slope $-(1+R)$. The value of the agent's factor services has increased to OD. The first-period borrowing for education of $B D$ is repaid with interest as $D B$, leaving a net income of $\mathrm{OE}$ to be allocated between consumption in the two periods of life. The agent therefore chooses his consumption point $F$ along $\mathbf{E E} \cdot 5$

The market-clearing rate of interest has not yet been determined. $\mathbf{R}$ will be set to clear the goods market such that the value of goods demanded by both students and workers is exactly equal to the value of goods manufactured by the workers. Now total output of goods is OD less BD, the value of capital diverted to education, thus the feasible allocations of manufactured output between agents of the two generations must be a line with slope of minus one and intercepts of (OD-BD) passing through point $B$. Point $F$, the representative agent's chosen consumption point, must lie both on the intertemporal budget constraint and the locus of feasible allocations. As B also lies on both lines, the two lines must coincide--the rate of interest 
necessary to clear the market being zero. This result accords, for an economy with zero population growth, with Samuelson's biological rate of interest and the Golden Rule. If agents have a positive rate of discount, then consumption in the first period will exceed that in the period during which they earn their incomes.

\section{Adjustment in the small, open economy}

Consider the country moving from autarky to producing and trading at exogenously determined relative prices. The resulting changes in goods production, along the transformation curve, may then be derived. The capital and labour stocks used in the production of $X$ and $Y$ are no longer exogenous--changes in the commodity price ratio induce changes in factor rewards, creating incentives for more or less investment in education, thereby resulting both in movements of physical capital between the education and the manufacturing sectors and in changes in the quantity of workers. However, these adjustments do not all take place simultaneously. Figure 2 is used to illustrate the changes in the economy.

Suppose that the autarkic price is $p$, then optimal long-run production for the closed economy occurs at point A on TT', the production possibility curve (PPC) corresponding to the long-run supplies of capital and labour to manufacturing at these prices. Suppose that the relative price of goods $Y$ were to rise from $p$ to $p^{\prime}$ when the country begins to trade with the rest of the world. Assume that the country remains diversified in its production of manufactures. The immediate consequence is a movement along the PPC, from A to $B$, such that the output of $X$ decreases and that of $Y$ increases. 
Additionally and in the same period, given the assumption that $Y$ is the labour-intensive industry, the price change will result in an increase in the wage rate and a fall in the return to capital. Demand for education rises, because students will expect the higher wage to persist into the following period and so will wish to invest more heavily in education, resulting in a movement of capital into the education sector and away from manufacturing. This induced Rybczynski effect causes, at the new price ratio, an expansion of production of the labour-intensive good (in this case $Y$ ) and a contraction of the production of the capital-intensive good $(X)$. Thus the capital exodus from manufacturing reinforces the production change resulting from the change in the relative commodity price and the short-run production point at the new price ratio is $C$, on Rybczynski line $R_{K} R_{K}^{\prime}$. The locus of combinations of $X$ and $Y$ that can then be produced in any period is not a single production possibilities curve but the locus of points each of which lies on a separate PPC, each conforming to a different endowment of capital and labour in manufacturing. Note that it is possible to have the phenomenon of Immiserizing reallocation [see Neary (1982)] where, during the adjustment period, the value of manufactured output declines when evaluated at the new prices. This, of course, occurs as a result of the investment in human capital, which takes an additional period to become productive.

The higher the capital-intensity in education in the current period, the greater the following period's supply of workers. So, after one period's delay, a second Rybczynski effect occurs as the supply of workers expands in size. Again this results in greater production of the labour-intensive good (Y) and reduced output of $X$, the capital-intensive good. The long-run 
production point $D$ must lie on Rybczynski line $R_{L} R_{L}$ outside TT'--any point on the original PPC could be produced using the original allocation of labour and capital. The investment in education permits substitution of capital for labour, resulting in a more efficient allocation of resources. This efficiency gain will show itself through a greater value of production of $X$ and $Y$ than could otherwise be achieved, of fsetting the initial costs of the educational investment. The long-run production possibilities, including points $A$ and $D$, can therefore be represented by an envelope to the $f$ ixed endowment PPCs.

Were $p$ to fall, then initially factors in manufacturing would be reallocated between industries and additional capital would flow into manufacturing from education, shifting production out beyond the original PPC and resulting in a higher output of $X$ and a lower output of $Y$. In the following period, the size of the labour force would decline (due to the reduced educational investment) and the PPC would move in along a Rybczynski line, further reducing $Y$ production and increasing the production of $X$. The final production point lies outside the original PPC, the value of goods manufacturing being maximized at the new prices with this new steady-state level of human capital.

Whenever the goods price ratio changes, students respond by choosing to consume and invest at the new steady-state levels corresponding to the new prices. Thus a steady state will be re-established in the following period. The burden of adjustment is therefore borne solely by the workers who chose their investment and first-period consumption on the expectation of one relative price, but end up facing different terms of trade. 
It seems clear that the government may influence the quantities of goods produced and the amount of educational investment by changing the domestic price ratio, $p$, or the rate of interest on borrowing, $R$. Such policies are discussed in the sections that follow. It should be noted in passing that, in the present case of a small country, there are no distortions and so no intervention is economically justified (and hence the optimal tariff is zero). Also the biological interest rate of zero is socially optimal. 6 Any policy adopted by the government that affects domestic production must therefore either be motivated by some non-economic objective or result from the country having some monopoly power in trade (that is, the country is not sma11). The former justification is discussed in section 4, the latter in section 5 .

\section{Bducation and Industrial Policies}

Suppose that the government of a country wishes to encourage students to acquire more education than they would otherwise have chosen in a free market. From equation (20), the quantity of education can be influenced by both the rate of interest and the price ratio. Inducing a change in the price ratio, by means of some form of taxation, will affect the allocation of resources not only between manufacturing and education, but also within the manufacturing sector itself. Therefore, let the government use the interest rate as the policy instrument. Suppose that the government were to subsidize the purchase of education, by offering a lower rate of interest on borrowing for that purpose. Thus the interest rate would be negative for loans for schooling. Let the adverse effects on government revenue of this scheme be offset either 
by a lump-sum tax on agents' earnings or by adjustments in the market interest rate for consumption loans.

The solution is illustrated in Figure 3, which is an extension of Figure 1. 7 Students face a lower interest rate on education loans and over-invest in education, compared with the free-market solution. Therefore the value of capital purchased for education rises from DE (equal to BD) to HK (equal to GH). The output from the educational investment is $A H$, while the cost as perceived by the student is HJ because the cost of borrowing is subsidized. The income available for the agent's consumption is $0 J$, whereas the value of manufacturing output is the smaller amount $O K$. In the absence of any further government intervention the interest rate will adjust to clear the market such that the sum of the chosen consumption quantities will exactly equal the available resources, corresponding to a point on $\mathrm{KK}^{\prime}$. The consumption-marketclearing interest rate must then be greater than zero and the intertemporal budget constraint will be JJ', with the optimal consumption point at $M$. A distortion in the education sector has generated an additional distortion in the timing of consumption. These distortions compound, rather than offset, one another and welfare may be improved by removing the consumption distortion. Suppose a lump-sum tax of JK were imposed on the agent. This would be just sufficient to pay the cost of the educational subsidy. The net income of the agent would be $\mathrm{OK}$ and the intertemporal budget line and the locus of feasible allocations would coincide, with a zero interest rate. Consumption would be at $L$, inferior to having no educational policy (F), but superior to $\mathrm{K}$. 
Were a positive interest rate charged for educational investment through, say, a tax surcharge, agents would acquire less than the optimal amount of education, corresponding in Figure 3 to some point between $A B$. Similar analysis to that for a subsidy would show that a lump-sum redistribution of the tax revenues is again superior to allowing the interest rate to clear the market.

Suppose that the government of a country wishes to raise the production of one of the traded goods above the level implied by international prices. Specifically, let the production objective be set in industry $Y$ (assumed to be relatively labour-intensive) such that the output of $Y$ must be at least $\hat{Y}$.

One way to attain this goal would be a production subsidy to the favoured industry. This would cause a reallocation of factors towards the $Y$ industry and raise the return to labour. In the new steady-state, as a result of increased educational investments, a relatively higher ratio of labour to capital will be employed in manufacturing. In Figure 4, long-run production moves from free-trade point $D$ to $B$ on the long-run production envelope where the subsidized price ratio is tangent to both the envelope and the underlying PPC.

Another means of reaching the production goal would be through the use of educational subsidies. These would raise the return to labour and induce more educational investment, resulting again in a higher capital-labour ratio in manufacturing and increased $Y$ production at the expense of output of $X$. Note that, in this instance, producers continue to face international prices and hence the production point $F$ cannot lie on the long-run production envelope. Thus the educational subsidy must be inferior to a production 
subsidy in that the quantity of $X$ sacrificed in producing $\hat{Y}$ is less with the former policy than the latter.

\section{Two-country general equilibrium}

Consider two countries, A and B, trading with each other in the commodities $X$ and $Y$. Suppose that the countries have identical technologies in producing these goods and in the supply of education. Furthermore, let the agents living in the countries have identical tastes and, initially, let the government interest rates be zero for both countries. Both countries have zero rates of population growth. Thus the countries can only differ in their relative endowments of labour and capital. 8

Assume that the countries are diversified in their comodity production in the trading equilibrium. Thus the common price ratio for the countries yields identical wage rates and returns to capital. Noting variables corresponding to the countries by superscripts, from (19) is derived:

$$
h^{\prime}\left(k_{E}^{A}\right)=\frac{r(p)}{w(p)}=h^{\prime}\left(k_{B}^{B}\right)
$$

The marginal product of capital used in education is the same for both countries. Given the assumption that the production functions are identical and homogeneous, the same ratio of capital to labour must be used in the education sector of both countries. Thus each student, regardless of nationality, obtains the same degree of education.

What can be said of the pattern of trade? Suppose country $A$ has a relatively higher capital endowment per agent than has country B, i.e.

$$
\mathbf{k}^{-\mathrm{A}}>\mathbf{k}^{-\mathrm{B}}
$$


At price $p$, let the capital-labour ratio in education be $k^{*}$ and let the quantity of education acquired by each student be $e^{\star}$. Thus the capital used in education by countries $A$ and $B$ depends on the absolute sizes of their labour forces, as do the supplies of workers to the manufacturing sector:

$$
\begin{aligned}
& \mathrm{K}_{\mathrm{B}}^{\mathrm{A}}=\mathrm{k}^{*} \mathrm{~N}^{-\mathrm{A}}, \quad \mathrm{K}_{\mathrm{B}}^{\mathrm{B}}=\mathrm{k}^{*} \mathrm{~B}^{-\mathrm{B}} \\
& L^{A}=\left(1+e^{*}\right) \mathbb{N}^{-A}, \quad L^{B}=\left(1+e^{*}\right)^{-B}
\end{aligned}
$$

The ratio of capital per worker available for commodity production in country A is then:

$$
k_{M}^{A}=\frac{K_{H}^{A}}{L^{A}}=\frac{K^{-A}-k^{*} \mathbb{N}^{-A}}{\left(1+e^{*}\right)^{-A}}=\frac{k^{-A}-k^{*}}{\left(1+e^{*}\right)}
$$

Similarly, for country B:

$$
k_{H}^{B}=\frac{k^{-B}-k^{*}}{\left(1+e^{*}\right)}
$$

Thus if $\mathrm{k}^{-\mathrm{A}}>\mathrm{k}^{-\mathrm{B}}$, then $\mathrm{k}_{M}^{-\mathrm{A}}>\mathrm{k}_{M}^{-\mathrm{B}}$. The country with the relatively higher

initial endowment of capital to labour will also have the relatively higher capital endowment in manufacturing and would therefore be expected to export the good which uses capital relatively intensively in its production. The model therefore yields the same prediction about the direction of the trade flow as does the standard Heckscher-Ohlin-Samuelson endownent model. Another way to interpret this result is that the greater the wealth per capita of a country, the smaller is the proportion of that wealth allocated to education. That is, education expenditures are a declining proportion of wealth, a prediction that is not obviously falsified by the data. 
A familiar argument used to explain the Leontief Paradox, the empirical finding that the United States though relatively well-endowed with capital was in fact the exporter of goods that were relatively labour intensive, is that the data used did not take into account international differences in human capital investments. The model developed here gives no support to that explanation as it predicts that, irrespective of whether or not account is taken of human capital accumulation, countries will export those goods that are intensive in the factors in which the countries are relatively abundant.

What if the two country's have the same relative endowments of the two factors but their rates of interest on borrowing differ, as a result of government policies? It is assumed that there is no integration of financial capital markets and so agents are only able to borrow and lend in their native countries. In particular, the country whose borrowing costs are higher will discount the future benefits of education more, and hence will demand less. Thus, from (19), the per capita allocation of capital to education in that country must be less than in the country which has the lower rate of interest. So for $R^{A}<R^{B}, k_{B}^{A^{*}}>k_{E}^{B^{*}}$ and $e^{A^{*}}>e^{B^{*}}$. Though their initial endowments, $\vec{k}^{-A}$ and $\vec{k}^{-B}$, are identical the actual ratios of capital to labour in manufacturing differ such that the country with the lower interest rate will have the relatively lower ratio of physical capital to labour, $k_{M}^{A}<k_{M}^{B}$. of course, the actual quantity of labour has not changed in either country but the skill component has. Thus country A, whose cost of borrowing is less than in country B, has a better educated workforce and, at international prices, will export the relatively labour intensive good. Country B, more heavily discounting the future, invests less in human capital 
creation and therefore retains relatively more physical capital. As a result it exports the relatively more capital-intensive good.

In this two-country framework, both countries have monopoly power in trade such that, by limiting the supplies of their exports or curtailing their import demands, they may change the terms of trade in their favour. Thus country A, for example, which exports $X$, the capital-intensive good, could impose an import tariff, raising the domestic price of $Y$. As was shown in section 3 , this would generate a two-period adjustment in $A$, resulting in a greater labour supply and a smaller quantity of capital available in manufacturing. The steady state will not be achieved in only two periods--the change in world prices ( $a$ fall in $p$ ) induced by the tariff will cause country B to reduce its human-capital investment, thus its factor supplies will change in the subsequent period (as will those of $A$ ) and a new world equilibrium price will be determined, resulting in a further round of adjustments in factor supplies in both countries. In a stable system these adjustments should eventually dampen down.

An "optimal" tariff may be derived, although the precise meaning of such an instrument in a dynamic system is hard to pinpoint. Though one of the countries may be passive, in the sense that it does not impose any retaliatory tariff, its factor supplies (as has been noted) will adjust over time in reaction to the tax imposed by the active country. Thus the supply response of the passive country will differ in the second period from what it was in the first. Therefore the tariff that was "optimal" initially would not be so in the subsequent period. " A steady state with the long-run "optimal" tariff could be reached only after several periods. A sequence of tariffs 
that are "optimal" could be determined, but the informational requirements for such a scheme (as to the stucture of demand and supply in the other country) are enormously greater than those needed in traditional static optimal tariff determination.

Barriers to trade such as tariffs are often the target of criticism, with attempts being made to convince governments to eliminate them [for example, the efforts of the GATT roundsl. In the framework discussed here there exists the ability for a country to exercise its monopoly power, without appearing to intervene in international exchange. Consider again country A, which is relatively capital-abundant and imports good $Y$. Suppose that its government were to subsidize borrowing for education. Then, at constant relative prices, the labour supply would rise relative to the stock of capital used in manufacturing. Thus domestic production of $Y$ would rise relative to production of $X$ resulting, in the two-country general equilibrium, in a terms of trade improvement for $A$, as the relative price of its export $X$ rises. Country B, which is relatively abundant in labour, could similarly improve its terms of trade by discouraging human capital accumulation, through raising borrowing costs.

\section{Sumary and Conclusions}

This paper has examined the acquisition of human capital in an overlapping-generations model of international trade with an endogenous interest rate. It was demonstrated that the equilibrium rate of interest, when there is no population growth, is zero--any other rate, irrespective of the means by which it is financed, reduces the welfare of the representative agent in the steady state. 
Adjustments to changes in price do not all occur instantaneously. The price changes induce changes in factor rewards and thereby change the incentives to invest in education. The long-run production possibilities curve was shown therefore to lie beyond that of the short run. Production objectives were found to shift factor supplies, increasing the relative supply of the factor used intensively in the production of the favoured good.

With identical technology, agents in different countries will acquire the same amounts of education. Thus investment in human capital is a declining proportion of the wealth of a country. The country with the relatively greater endowment of capital will, as in the HeckscherOhlin-Samuelson model, export the good which uses capital relatively intensively in its production. Differences in the costs of borrowing will generate trade, with the country in which borrowing is cheaper having a better educated labour force. Alternatively, a government may use educational policies to exploit its monopoly power in trade, in those circumstances where tariffs cannot be imposed. 


\section{Footnotes}

* The authors wish to thank James Davies, Richard Manning, and Cayetano Paderanga Jr. for their advice and comments. Wooton acknowledges the support of the Social Sciences and Humanities Research Council of Canada.

1 All labour is, in fact, converted into skilled labour and thus, ex post, is an input into a specific activity. However, unskilled labour can be used in either of the other industries.

2 Education is presumed to have no public goods aspect.

3 Alternatively, the capital could be held by some outside agency that rents it to workers and consumes the proceeds.

4 Alternative assumptions about expectations may be made without significant changes in the results.

5 It is assumed that the indirect utility function is concave in the values of consumption, resulting in an interior solution.

6 It can easily be shown that a zero interest rate maximizes the welfare of the representative consumer.

7 A mathematical derivation of the solution is available from the authors.

8 Differences in rates of population growth would result in different autarkic interest rates for each country and no trading steady-state.

9 Similar problems with tariff policy in a dynamic model are discussed in Kiguel and Wooton (1985). 


\section{References}

Bhagwati, Jagdish $\mathrm{N}$, and Srinivasan, T.N. "Optimal Intervention to Achieve Non-economic Objectives." Review of Bconomic Studies 36 (1) (January 1969): 27-38.

Bhagwati, Jagdish N. "Shifting Comparative Advantage, Protectionist Demands and Policy Response." In Jagdish N. Bhagwati, editor, Import Competition and Response. Chicago: Univ. of Chicago Press (1978): 153-184.

Dinopoulos, Elias. "Import Competition, International Factor Mobility, and Lobbying Responses: The Schumpeterian Industry Case." Journal of International Economics (1983): 395-410.

Findlay, Ronald, and Kierzkowski, Henryk. "International Trade and Human Capital: A Simple General Equilibrium Model." Journal of Polltical Economy 91 (December 1983): 957-978.

Kenen, Peter. "Nature, Capital, and Trade." Journal of Political Economy 73 (October 1965): 437-460.

Kiguel, Miguel A., and Wooton, Ian. "Tariff Policy and Eequilibrium Growth in the World Economy." Journal of Development Bconomics 19 (September-October 1985): 187-198.

Mussa, Michael. "Dynamic Adjustment in the Heckscher-Ohlin-Samuelson Model." Journal of Political Economy 86 (October 1974): 775-91. Mussa, Michael. "Government Policy and the Adjustment Process." In Jagdish N. Bhagwati, editor, Import Competition and Response. Chicago: Univ. of Chicago Press (1978): 73-120. 
Neary, J. Peter. "Intersectoral Capital Mobility, Wage Stickiness, and the Case for Adjustment Assistance." In Jagdish N. Bhagwati, editor, Import Competition and Response. Chicago: Univ. of Chicago Press (1978): $\quad 39-67$.

Samuelson, Paul A. "An Exact Consumption-1oan Model of Interest with or without the Social Contrivance of Money." Journal of Political Bconomy 64 (December 1958): 467-482. 
24

FIGURB 1

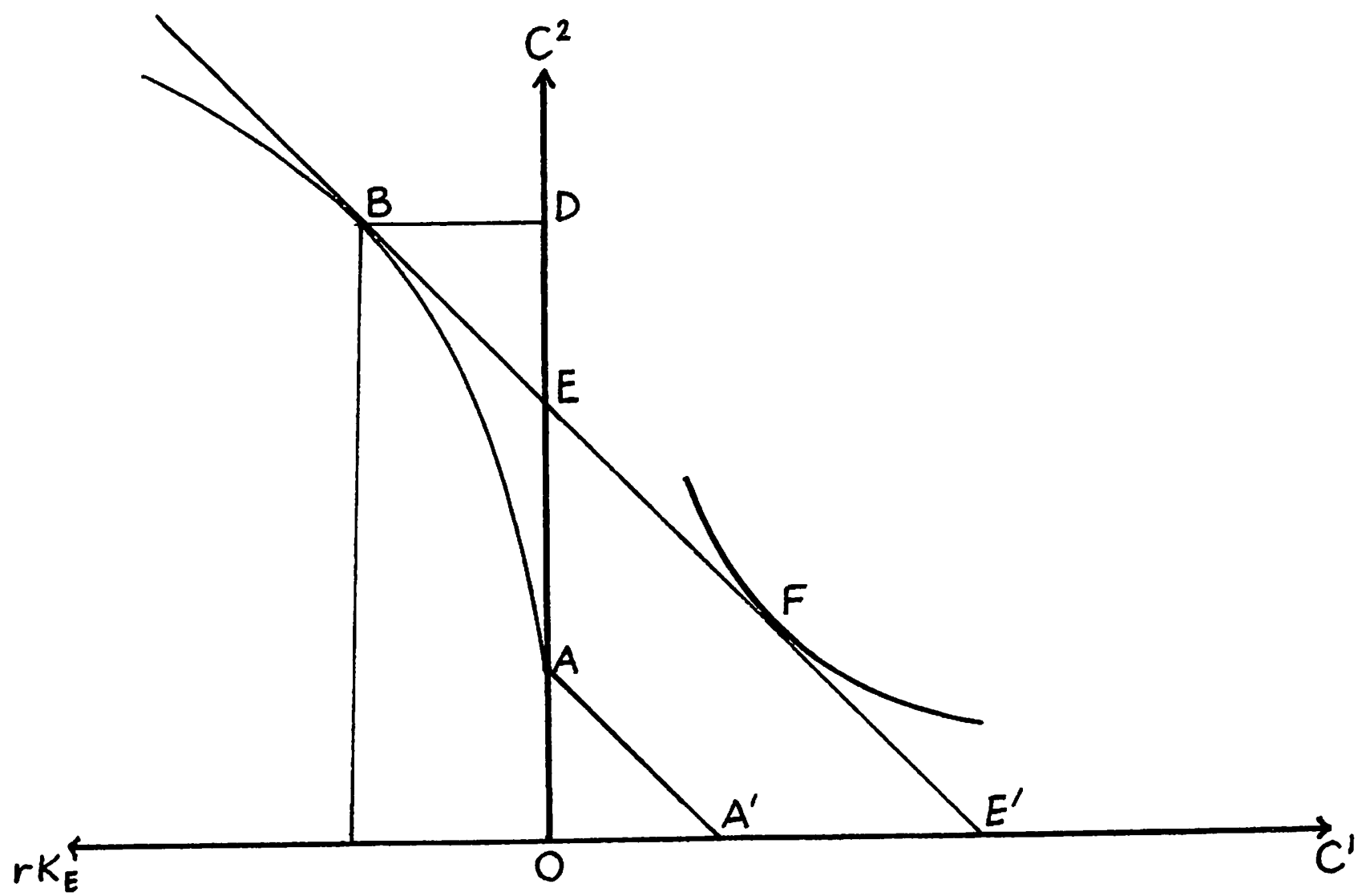


FIGURB 2

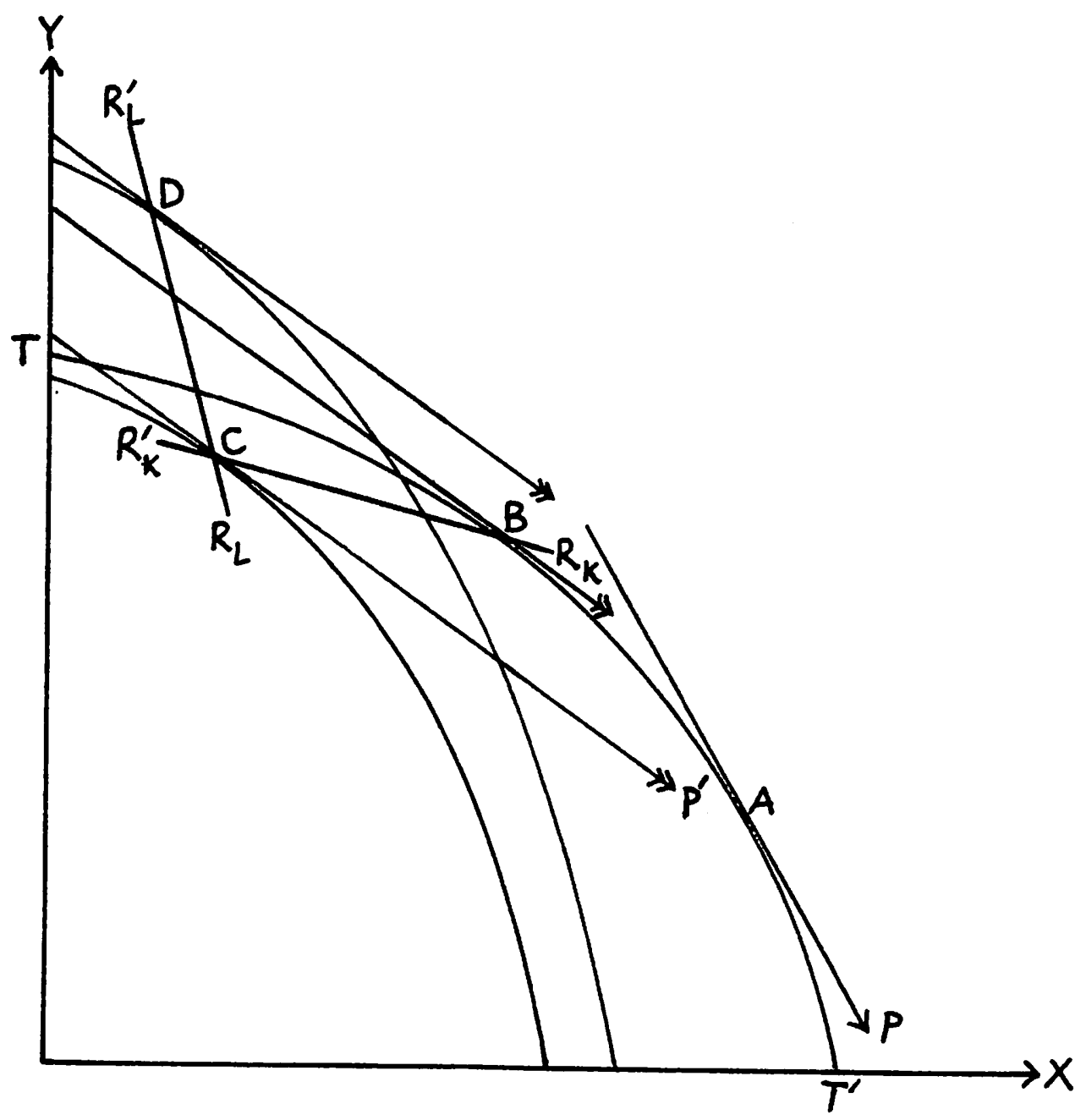


26

FIGURE 3

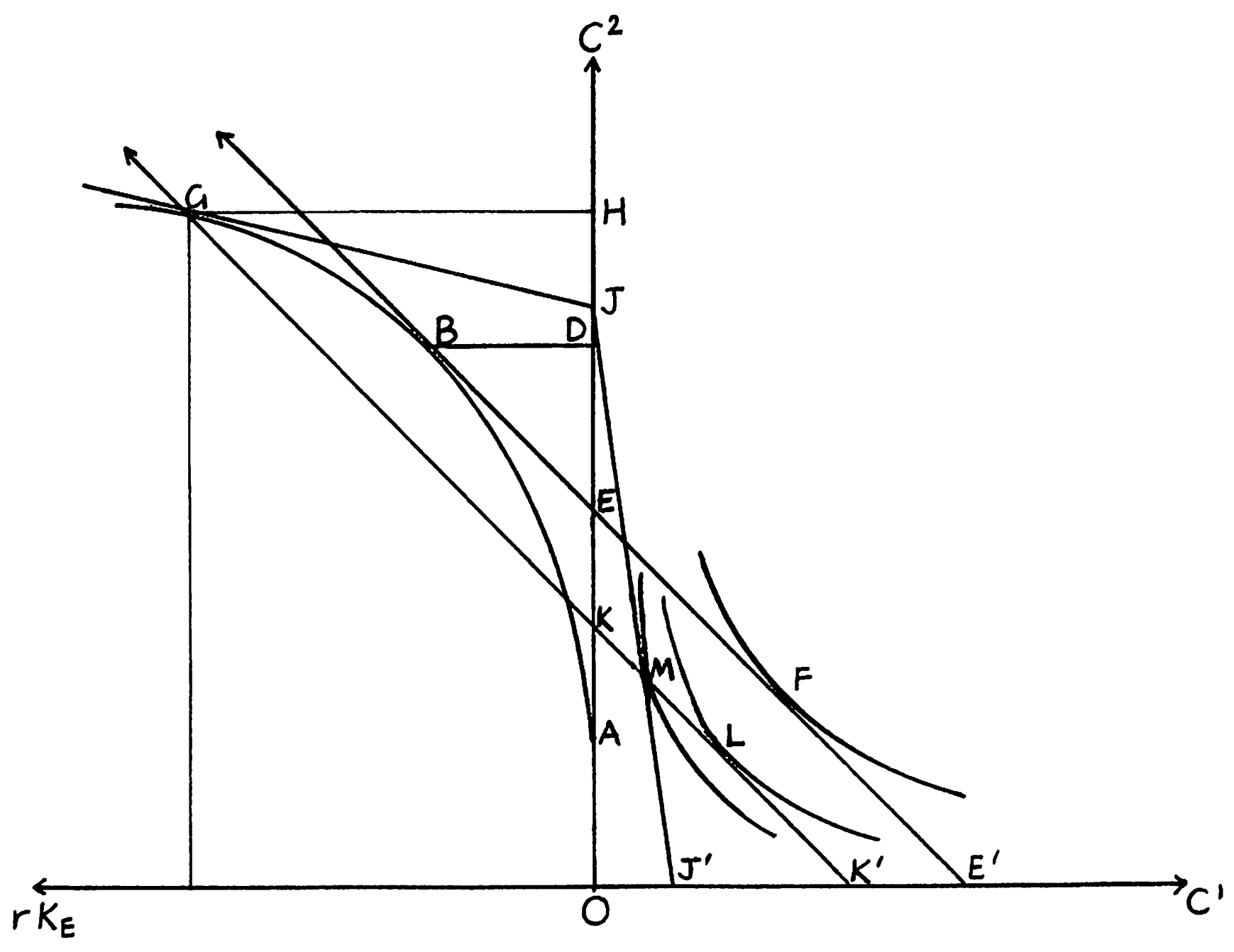


FIGURB 4

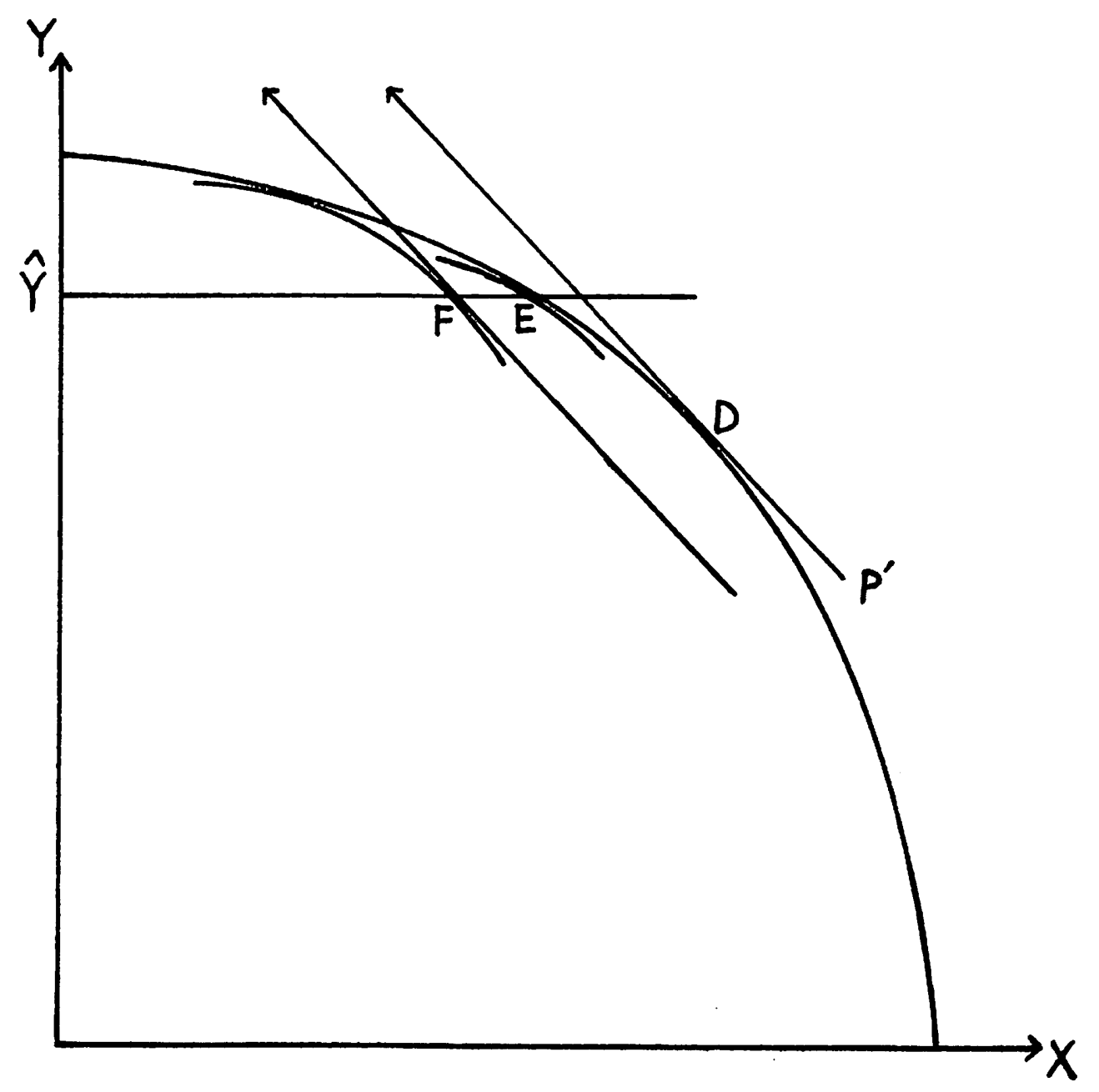


8401C Harrison, Glenn w. and Manning, Richard. BEST APPROXIMATE AGGREGATION OF INPUT-OUTPUT SYSTEMS.

8402C Parkin, Michael. CORE INFLATION: A REVIEW ESSAY.

8403C Blomqvist, Àke, and McMahon, Gary. SIMULATING COMMERICAL POLICY IN A SMALL, OPEN DUAL ECONOMY WITH URBAN UNEMPLOYMENT: A GENERAL EQUILIBRIUM APPROACH.

8404C Wonnacott, Ronald. THE THEORY OF TRADE DISCRIMINATION: THE MIRROR IMAGE OF VINERIAN PREFERENCE THEORY?

8405C Whalley, John. IMPACTS OF A 50\% TARIFF REDUCTION IN AN EIGHT-REGION GLOBAL TRADE MODEL.

8406C Harrison, Glenn W. A GENERAL EQUILIBRIUM ANALYSIS OF TARIFr REDUCTIONS.

8407C Horstmann, Ignatius and Markusen, James R. STRATEGIC INVESTMENTS AND . THE DEVELOPMENT OF MULTINATIONALS.

8408C Gregory, Allan $W$. and McCurdy, Thomas H. TESTING THE UNBIASEDNESS HYPOTHESIS IN THE FORWARD FOREIGN EXCHANGE MARKET: A SPECIFICATION ANALYSIS.

8409C Jones, Ronald $\mathrm{C}$. and Klerzkowsk1, Henryk. NEIGHBORHOOD PRODUCTION STRUCTURES WITH APPLICATIONS TO THE THEORY OF INTERNATIONAL TRADE.

$8410 \mathrm{C}$ Weller, Paul and Yano, Makoto. THE ROLE OF FUTURES MARKETS IN INTERNATIONAL TRADE: A GENERAL EỌUILIBRIUM APPROACH.

8411C Brecher, Richard A, and Bhagwat1, Jagdish N. VOLUNTARY EXPORT RESTRICTIONS VERSUS IMPORT RESTRICTIONS: A WELFARE-THEORETIC COMPARISON.

8412C Ethier, Wilfred J. ILLEGAL IRMIGRATION.

8413C Eaton, Jonathon and Gene M. Grossman. OPTIMAL TRADE AND INDUSTRIAL POLICY UNDER OLIGOPOLY.

8414C Wooton, Ian. PREFERENTIAL TRADING AGREEMENTS - A 3xn MODEL.

8415C Parkin, Michael. DISCRIMINATING BETWEEN KEYNESIAN AND CLASSICAL THEORIES OF THE BUSINESS CYCLE; JAPAN 1967-1982

8416C Deardorff, Alan V. FIRless FIRwocs: HOW PREFERENCES CAN INTERFERE WITH THE THEOREMS OF INTERNATIONAL TRADE.

8417C Greenwood, Jercmy. NONTRADED GOODS, THE TRADE BALANCE, AND THE BALANCE OF PAYTENTS. 
8418C Blomqvist, Ake and Sharif Mohammad. CONTROLS, CORRUPTION, AND COMPETITIVE RENT-SEEKING IN LDCS.

8419C Grossman, Herschel I. POLICY, RATIONAL EXPECTATIONS, AND POSITIVE ECONOMIC ANALYSIS.

8420C Garber, Peter $M$. and Robert G. King. DEEP STRUCTURAL EXCAVATION? $\triangle$ CRITIOUUE OF EULER EQUATION METHODS.

S42IC Barro, Robert J. THE BEHAVIOR OF U.S. DEFICITS.

8.422C Persson, Torsten and Lars E.0. Svensson. INTERNATIONAL BORROWING AND TIME-CONSISTIENT FISCAL POLICY.

8.i23c. Obstfeld Maurice. Capital controls, the dunl exchunge RATE, AND DEVALUATION.

S:24C Kuhn, Peter. UNION PRODUCTIVITY EFTECIS AND ECONOMIC EFFICIENCY.

3425C Hamilton, Bob and John Whalley. TAX TREATMENT OF HOUSING IN $A$ DYNAMIC SEOUENCED GENERAL EOUILIBRIUN MODEL. .

$\because \because 26 \mathrm{C}$ Hamilton, Bob, Sharif Mohammad, and John Whalley, RENT SEEKING AND THI NORTH-SOUTI TERMS OF TIADF.

8427C Adams, Charles and Jeremy Greenwod. DUAL BXCHANGE RATF SYSTEMS ANI) CAPITAL CONTROLS: $\Lambda$ N INVESTIGATION.

8428 Loh, Choon Cheong and Michael R. Veall. $\Lambda$ NOTE ON SOCIAL SECURITY ANM PRIVATE SAVINGS IN SINGAPORE.

8.429 Whalley, John. REGRESSION OR PROCRESSION: THE TAYING OUESTION OF INCIDENCE ANALYSIS.

3430 Kuhn, Peter. WGES, EFFORT, AND INCENTIVE-COMPATIBILITY IN LITE-CYCLE EMTPOYMENT CONTRACTS .

8431 Greenwood, Jerery and Kent P. Kimbrough. AN INVESTIGATION IN THE THEORY OF FOREIGN EXCHANGE CONTROLS.

8432 Greenwood, Jeremy and Kent P. Kimbrough. CAPITAL CONTROLS AND THE INTERNATIONAL TRANSMISSION OF FISCAL POLICY.

8433. Nguyen, Trien Trien and John Whalley. EOUILIBRIUM UNDER PRICE CONTROLS WITH ENDOSENOUS TRANSACTIONS COSTS.

8434 Adams, Charles and Russell S. Boyer. EFFICIENCY $\Lambda$ ND A SIMPLE MODEL OF EXCILANGE RATE DETERMINATION. 
8435 Kuhn, Peter. UNIONS, ENTREPRENEURSHIP, AND EFFICIENCY.

8436 Hercowitz, Zvi and Efraim Sadka. ON OPTTMAL CURRENCY. SUBSTITUTION POLICY AND PUBLIC FINANCE.

8437 Lenjosek, Gordon and John Whalley. POLICY EVALUATION IN A SMALL OPEN PRICE TAKING ECONOMY: CANADIAN ENERGY POLICIES.

8438 Aschauer, David and Jeremy Greenwood. MACROECONOMIC EFFECIS OF FISCAL POLICY.

8439C Hercowitz, Zv1. ON THE DETERMINATION OF THE EXTERNAL DEBT: THE CASE OF ISRAEL.

8440C Stern, Robert M. GLOBAL DIMENSIONS AND DETERMINANTS OF INTERNATIONAL TRADE AND INVESTMENT IN SERVICES.

$8441 \mathrm{C}$ Deardorff, Alan V. COMPARATIVE ADVANTAGE AND INTERNATIONAL TRADE AND INVESTMENT IN SERVICES.

8442C Daly, Donald J. TECHNOLOGY TRANSFER AND CANADA'S COMPETITIVE PERFORMANCE.

844.3C Grey, Rodney de C. NEGOTIATING ABOUT TRADE AND INVESTMENT IN SERVICES.

8444C Grossman, Gene $M$. and Carl Shapiro. NORMATIVE ISSUES RAISED BY INTERNATIONAL TRADE IN TECHNOLOGY SERVICES.

3445C Chant, John $F$. THE CANADIAN TREATMENT OT FOREIGN BANKS: A CASE STUDY IN THE WORKINGS OF THE NATIONAL TREATMENT APPROACH.

8446C Aronson, Jonathan D. and Peter F. Cowhey. COMPUTER, DATA PROCESSING, AND COMMUNICATION SERVICES.

8447C Feketekuty, Geza. NEGOTIATING STRATEGIES FOR LIBERALIZING TRADE AND INVESTMIENT IN SERVICES.

8448C Harrison, Glenn, W. and E.E. Rutstrom. THE EFFECT OF MANUFACTURING SECTOR PROTECTION ON ASEAN AND AUSTRALIA: A GENERAL ENUILIBRIUM ANALYSIS. 
8501C Greenwood, Jeremy and Kent P. Kimbrough. FOREIGN EXCHANGE CONTROLS IN A BLACK MARKET ECONOMY.

8502C Horstmann, Ignatius and James R. Markusen. UP YOUR AVERAGE COST CURVE: INEFFICIENT ENTRY AND THE NEIV PROTECTIONISM.

8503C Gregory, Allan $\mathrm{H}$. TESTING INTEREST RATE PARITY AND RATIONAL EXPECTATIONS TOR CANADA AND THE UNITED STATES.

8504C Kuhn, Peter and Ian Hooton. INTERNATIONAL FACTOR MOVEMENTS IN THE PRESENCE OF A FIXED FACTOR.

8505C Wong, Kar-yiu. GAINS FROM GOODS TRADE AND FACTOR MOBILITY.

8506C Veller, Paul and Makoto Yano. FUTURES MARKETS, REAL INCOME, AND SPOT PRICE VARIABILITY: $\Lambda$ GENERAL EOUUILIBRIUM APPROACH.

8507C Diewert, H.E. THE EFFECTS OF AN INNOVATION: A TRADE THEORY APPROACH.

8508C Ethier, Wilfred J. FOREIGN DIRECT INVESTMENT AND THE MULTINATIONAL FIRM.

8509C Dinopoulos, Ellas. INSIDE THE BLACK BOX: (IN) TANGIBLE ASSETS, INTRA-INDUSTRY INVESTMENT AND TRADE.

8510C Jones, Richard, John thalley, and Randall Higle. REGIONAL IMPACTS OF TARIFFS IN CANADA: PRELIMINARY RESULTS FROM A SMALL DIMENSIONAL NURERICAL GENERAL EOUILIBRIUM MODEL.

8511C Whalley, John. HIDDEN CHALLENGSS IN RECENT APPLIED GENERAL EỌUIL IBRIUM EXERCISES.

8512C Smith, Bruce. SOME COLONIAL EVIDENCE ON TTO THEORIES OF MONEY: MARYLAND AND THE CAROLINAS.

3513C Grossman, S.J., A. Melino, and R.J. Sh1ller. ESTIMATING THE CONTINUOUS TIME CONSUMPTION BASED ASSET PRICING MODEL.

8514C Romer, Paul R. TAX EFFECTS AND TRANSACTION COSTS FOR SHORT TERM MARKET DISCOUNT BONDS.

8515C McCallum, Bennett $T$. ON CONSEOUENCES AND CRITJCISMS OF MONETARY TARGETING.

8516C Dinopoulos, Ellas and Ian Wooton. A NORTH-SOUTH MODEL OF INTERNATIONAL JUSTICE.

8517C Huffman, Gregory W. A DYNAMIC EQUILIBRIUM MODEL OF ASSET PRICES AND TRANSACTION VOLUME.

8518C Huffman, Gregory W. AN ALTERNATIVE VIEW OF OPTIMAL SEIGNIORAGE. 8519C Huffman, Gregory W. ASSET PRICING WITH HETERGENEOUS ASSETS. 
8520C Hercowitz, Zvi. THE REAL INTEREST RATE AND AGGREGATE SUPPLY.

8521C Davies, James and Michael Hoy. COMPARING INCONE DISTRIBUTIONS UNDER AVERSION TO DOWNSIDE INEQUALITY.

8522C Nguyen, Trien $T$. and John Whalley. COEXISTENCE OF EQUILIBRIA ON BLACK AND WHITE MARKETS.

8523C Clarete, Ramon and John Whalley. INTERACTIONS BETWEEN TRADE POLICIES AND DOMESTIC DISTORTIONS: THE PHILIPPINE CASE.

8524C Hamilton, Bob, Sharif Mohammad, and John Whalley. APPLIED GENERAL EOQUILIBRIUM ANALYSIS AND PERSPECTIVES ON GROWTH PERFORMANCE.

8525C Huffman, Gregory W. THE LAGGED EFFECTS OF POLICY ON THE PRICE LEVEL.

8526C Laidler, David. FISCAL DEFICITS AND INTERNATIONAL MONETARY INSTITUTIONS.

8527C Goodfriend, Marvin. MONETARY MYSTIQUE: SECRECY AND CENTRAL BANKING.

8528C Nguyen, Trien T. and John Whalley. GENERAL EQUILIBRIUM ANALYSIS OF PRICE CONTROLS A TWO-SECTOR COMPUTATIONAL APPROACH.

8529C Heckman, James J. and V. Joseph Hotz. AN INVESTIGATION OF THE LABOR MARKET EARNINGS OF PANAMANIAN MALES: EVALUATING SOURCES OF INEQUAL ITY.

8530C Greenwood, Jeremy and Gregory W. Huffman. A DYNAMIC EQUILIBRIUM MODEL OF INFLATION AND UNEMPLOYMENT.

8531C Freeman, Scott. INSIDE MONEY, MONETARY CONTRACTIONS, AND WELFARE.

8532C Paderanga, Cayetano Jr. and Ian Wooton. A POSITIVE VIEW OF INFANT INDUSTRIES.

8533C St-Hilaire, France and John Whalley. A MICROCONSISTENT DATA SET FOR CANADA FOR USE IN REGIONAL GENERAL EQUILIBRIUM POLICY ANALYSIS.

8534C Whalley, John. OPERATIONALIZING WALRAS: EXPERIENCE WITH RECENT APPLIED GENERAL EQUILIBRIUM TAX MODELS.

8535C Melvin, James R. THE GENERAL NON-EQUIVALENCE OF TARIFFS AND IMPORT QUOTAS. 
8601C Greenwood, Jeremy and R. Preston McAfee. EXTERNALITIES AND ASYMMETRIC INFORMATION.

8602C Dinopoulos, Elias and Mordechai E. Kreinin. IMPORT OUOTAS AND VERS: A COMPARATIVE ANALYSIS IN A THREE-COUNTRY FRAMEWORK.

8603C Clarete, Ramon and John Whalley. COMPARING THE MARGINAL WELFARE COSTS OF COMMODITY AND TRADE TAXES.

8604C Wigle, Randy. CANADIAN TRADE LIBERALIZATION: SCALE ECONOMIES IN A GLOBAL CONTEXT.

8605C Parkin, Michael. DOMESTIC MONETARY INSTITUTIONS AND FISCAL DEFICITS .

8606C Dinopoulos, Elias and Ian Wooton. INTERNATIONAL TRADE AND THE ACOUISITION OF SKILLS. 